\title{
ACESSO E CUIDADO DE HOMENS COM DOENÇA FALCIFORME E PRIAPISMO NA URGÊNCIA E EMERGÊNCIA DE FEIRA DE SANTANA
}

\author{
Heros Aureliano Antunes da Silva Maia ${ }^{1}$; Evanilda Souza de Santana Carvalho²; Aline \\ Silva Gomes Xavier ${ }^{3}$ e José de Bessa Júnior ${ }^{4}$. \\ 1. Bolsista PIBIC/FAPESB, Graduando em Medicina, Núcleo Interdisciplinar de Estudos Sobre Desigualdades em Saúde, \\ Universidade Estadual de Feira de Santana, e-mail: herosmaia@hotmail.com \\ 2. Orientador, Departamento de Saúde, Universidade Estadual de Feira de Santana, e-mail: beltrano@ provedor.br \\ 3. Doutoranda do PPGSC/UEFS. Bolsista da FAPESB. Núcleo Interdisciplinar de Estudos sobre Desigualdades em Saúde \\ (NUDES), Departamento de Saúde, Universidade Estadual de Feira de Santana, e-mail: asgx80@ gmail.com \\ 4. Núcleo Interdisciplinar de Estudos Sobre Desigualdades em Saúde, Departamento de Saúde, Universidade Estadual de \\ Feira de Santana, e-mail: josedebessa@gmail.com
}

PALAVRAS-CHAVE: Doença Falciforme; Priapismo; Disfunção Erétil.

\section{INTRODUÇÃO}

Priapismo é a ereção peniana total ou parcial contínua por mais de 4 horas acompanhada ou não de estímulo sexual e orgasmo (BRODERICK, 2012). Uma das causas do priapismo são as hemoglobinopatias, como a doença falciforme (DF). Sua incidência se relaciona ao percentual de afrodescendentes da cada região, o estado da Bahia apresenta a maior incidência da DF; 1:650 nascidos vivos (CORDEIRO et al, 2014).

Homens com DF vivenciam priapismo isquêmico, que ocorre por falha da drenagem sanguínea do corpo cavernoso, culminando em sua rigidez (CHROUSER et al, 2011). O priapismo pode ocorrer de modo agudo ou recorrente, este último dura menos de 3 horas, não cursa com dor intensa e tende a cessar espontaneamente (VICARI \& FIGUEIREDO, 2007). De forma geral, o priapismo é uma emergência médica urológica que requer pronto atendimento ou mesmo manejo cirúrgico para prevenir complicações como disfunção erétil irreversível (ROGHMANN et al, 2013).

Assim, este estudo foi norteado pela seguinte questão: Como homens com DF e priapismo acessam cuidados na rede de urgência e emergência de Feira de Santana? O objetivo geral é compreender como os homens com DF e priapismo acessam os cuidados na rede de urgência e emergência de Feira de Santana e o objetivo específico é descrever as experiências de acesso e cuidado destes homens.

\section{METODOLOGIA}

Estudo de abordagem qualitativa, exploratório. Participaram do estudos homens com DF e experiência anterior de priapismo, maiores de 18 anos, cadastrados no Centro de Referência à Pessoa com Doença Falciforme no município de Feira de Santana. Para produção de dados empíricos foi utilizada a Técnica de Associação Livre de Palavras (TALP) e o Procedimento de Desenhos-Estórias com Tema (PDET). Foi utilizada ainda a técnica de entrevista semiestruturada (TES), que tem como característica um roteiro com perguntas abertas.

Os dados advindos da entrevista semiestruturada e do TALP foram submetidos à análise de conteúdo proposta por Bardin (2011), os advindos do PDET foram analisados segundo o modelo proposto por Coutinho (2001). Utilizou-se ainda a Triangulação (MARTHA et al, 2007) para convergência dos dados. Respeitaram-se todas as recomendações da Resolução 466/12 sob o parecer 1.440.239.

\section{RESULTADOS E DISCUSSÃO}


Foram entrevistados sete homens, com idades entre 27 e 48 anos. Seis se identificaram como negros ou pardos. Maioria possui baixa escolaridade, renda familiar média de um salário mínimo; apenas um referiu ocupação laboral enquanto os demais se encontravam desempregados, aposentados e em auxilio doença. Cinco homens eram HbSS e dois HbSC. Somente três tiveram diagnóstico da DF ao nascer, os demais receberam diagnóstico tardio. $\mathrm{O}$ primeiro episódio de priapismo ocorreu entre os 15 e 20 anos de idade, durando menos de 4 horas para maioria dos participantes. Cinco referiram já ter usado os serviços de urgência e emergência por causa do priapismo, dois referiram nunca ter utilizado as emergências pelo priapismo. Para deslocar-se de casa a esses serviços, todos utilizam ônibus, bicicleta, táxi ou vão levados por vizinhos e por vezes a pé.

Ao versar sobre como acessam cuidados na rede de urgência e emergência de Feira de Santana, na ocorrência do priapismo, os homens revelaram suas experiências o que nos permitiu organizá-las em três categorias temáticas, a primeira delas intitulada: "Experiência do priapismo: significados, percepções e estratégias de manejo em domicílio". O priapismo é entendido como uma falta de saúde, uma deficiência, uma ereção dolorosa involuntária imprevisível, mais frequente à noite. Em suas primeiras ocorrências, não raro é o homem desconhecer a ligação do priapismo à DF, o que permite atribuir ao priapismo significado de maior virilidade ou potência sexual. O priapismo gera situações de constrangimento ao homem com DF em relação às pessoas ao seu redor, seja no trabalho, amigos ou na própria família. Assim, esses homens se isolam em domicílio, fazem usos de chás, banhos com água fria, exercícios, se masturbam ou buscam relações sexuais com parceiras na tentativa de provocar a detumescência do pênis.

"Tomava banho, se molhava, botava gelo, já me ensinaram pra banhar o pênis com aroeira, diziam que era bom [...] tomava chá de cana, tomava muito banho, ficava muito tempo embaixo d'água no banheiro, até aquela sensação de dormência passar, parecia que estava anestesiado. Não passava, aliviava. Passava com o tempo, a gente esquecia também na mente." - Hércules (TES).

"Em casa quando tenho (priapismo) eu boto um paninho com água morna, dou uma volta e já era." - Ares (TALP).

O homem é falocêntrico, põe sua erotização no pênis e este recebe significados de procriação, virilidade, prazer e paternidade. $\mathrm{O}$ pênis é o órgão que define a masculinidade, sua falta coloca a mesma em dúvida (XAVIER et al, 2014).

A segunda categoria se intitulou: "Acesso aos serviços de urgência e emergência: fatores motivadores e limitantes". A falha das estratégias em domicilio aliado à dor se tornar insuportável motiva o homem com DF e priapismo a buscar as emergências, geralmente acompanhado de uma pessoa de sua confiança, o que revela que as emergências são vistas como última opção. A vergonha por sua vez prejudica o acesso, seja dificultando o uso de transportes públicos pela visibilidade da ereção, ou se tornando presente quando o homem com DF e priapismo pressupõe que será atendido por profissionais do sexo feminino nas emergências, preocupação também vista em outro estudo (ADDIS et al, 2007), o que afeta a imagem do homem como ser invulnerável, o colocando em posição de fraqueza.

"Vergonha. Às vezes é um pouco vergonhoso você chegar numa situação dessas (em priapismo) no hospital, com várias enfermeiras.” - Hades (TES).

A terceira categoria, "Experiências do priapismo nos serviços de urgência e emergência", revelou que homens com DF e priapismo vivenciam experiências constrangedoras nesses serviços tanto pelos profissionais de saúde quanto por demais funcionários dos serviços de apoio, como recepcionistas ou maqueiros. Tais experiências se baseiam no preconceito pela falta de conhecimento sobre a DF e o priapismo, ou associação do priapismo com distúrbios psicológicos sexuais, práticas masturbatórias ou atrelar a figura do homem com ereções em situações públicas ao estereótipo de abusador sexual. 
Porém, não raro que seja nos serviços de urgência e emergência que o homem obtenha esclarecimentos, sejam educados e informados pelos profissionais de saúde sobre a DF, sobre complicações do priapismo e o que fazer para maneja-lo. Além disso, os profissionais de saúde orientam os homens com DF e priapismo a buscarem a discrição e quando possível o isolam como meio de manter a privacidade. O cuidado também se dá através de analgesia, da hidratação, e em casos graves, através da cirurgia de shunt peniano. Essa cirurgia desperta sentimentos de medo e apreensão sobre a potência sexual futura no homem. Há escassez de profissionais aptos a realizar tal procedimento, o que retarda o tratamento e aumenta o risco de complicações, como a disfunção erétil. O homem com DF e priapismo sente medo dessa complicação, e reflete que caso ocorra, ele estará vulnerável a depressão e a possibilidade de cometer suicídio.

"Foi um procedimento muito delicado e doloroso [...] acabou eu tendo eu sequela [...] sexo não é só penetração. Então eu aprendi a lidar [...] no início foi complicado de lidar, não vou mentir, porque a ereção do homem é um bem que se você tirar, você tira o que quiser do homem, mas não tire a ereção do homem que o homem fica doido, até suicídio ele faz." Zeus (TES).

Apesar de a maioria temer a impotência sexual, um dos participantes relatou que é possível conviver com a disfunção erétil desde que ocorra uma ressignificação da relação sexual, de forma que o prazer para o homem não esteja vinculado unicamente à penetração.

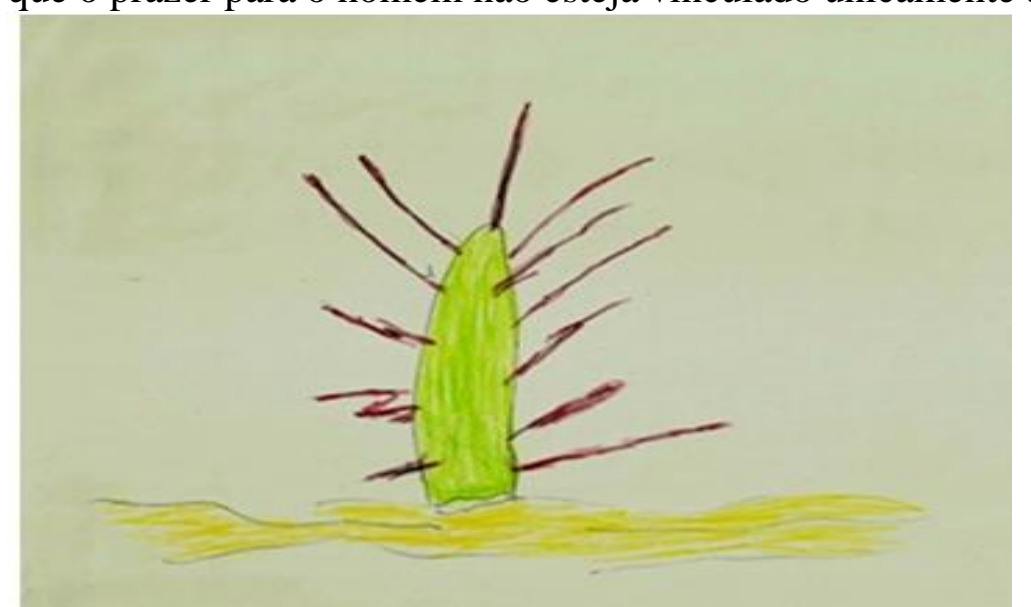

Figura 1 - Desenho Estória com Tema, intitulado "Priapismo do Deserto": "Quando eu cheguei à emergência, eu vi que aquela coisa que eu achava que era bom, na verdade era ruim, porque acabei indo para uma sala de cirurgia, eu acabei tendo meu órgão todo preenchido por agulhas, sensação dolorida [...] por isso desenhei o mandacaru, porque foi como eu senti meu órgão todo preenchido por agulhas, tipo espinho, isso ficou marcado dentro de mim" - Zeus.

A disfunção erétil é previsível em $90 \%$ dos casos de priapismo isquêmico com duração maior que 24 horas (BRODERICK, 2012). Em estudo nigeriano, após tratamento farmacológico ou cirurgia de shunt peniano, apenas quatro de 18 pacientes com priapismo mantiveram função erétil satisfatória, sete obtiveram ereções fracas e sete não obtiveram ereções após três meses de tratamento (EKEKE et al, 2015).

\section{CONSIDERAÇÕES FINAIS}

Este estudo possui limitações; participaram do mesmo apenas sete homens com DF que já vivenciaram priapismo. Ademais, dois participantes nunca utilizaram os serviços de emergência motivados pelo priapismo. A atribuição de diferentes significados ao priapismo pelos homens com DF é influenciada pelo acesso ao diagnóstico precoce da DF, de modo que ao desconhecer a relação etiológica do priapismo com a DF o homem pode entendê-lo como 
maior virilidade/potência sexual. Percebemos que a vergonha e o constrangimento permeiam as experiências dos homens com priapismo, seja em seu domicílio, em situações sociais ou nos serviços de saúde, prejudicando o acesso aos mesmos.

$\mathrm{O}$ acesso aos serviços de emergência é motivado pela falha das estratégias em domicílio em cessar a ereção e a dor. Porém, o acesso é prejudicado pelo constrangimento e pelas condições financeiras, como em pedir ajuda ou usar transportes públicos pela visibilidade da ereção. Nos serviços de emergência, profissionais de saúde e apoio que desconhecem a DF e o priapismo promovem ainda mais constrangimento ao homem com DF e priapismo, associando a figura do homem em ereção pública ao estereótipo de abusadores sexuais. Ainda assim, são nas emergências que a relação etiológica entre o priapismo e a DF é esclarecida aos homens, que ainda são ensinados em como manejar o priapismo e informados sobre o risco de complicação como a disfunção erétil pelos profissionais de saúde.

Este estudo indica que é necessária uma revisão nos protocolos existentes para definir qual o tempo limite de espera para o acesso aos tratamentos pelo homem com DF e priapismo, levando em consideração as particularidades de cada país, como as condições de mobilidade pelos meios de transportes e a qualidade e a eficiência em se obter um atendimento rápido nos serviços de emergência em cada local. Além disso, ressalta-se a importância do diagnóstico precoce da $\mathrm{DF}$, da orientação dos familiares e do dever que possuem os profissionais de saúde que acompanham os meninos e jovens homens com DF e seus cuidadores de informar e educar sobre o priapismo antes que este ocorra, para permitir o autocuidado e prevenção de complicações.

\section{REFERÊNCIAS}

ADDIS, G. et al. The physical, social and psychological impact of priapism on adult males with sickle cell disorder. Chronic Illn. Vol. 3, n. 2, p. 145-154, jun. 2007.

BARDIN, L. Análise de conteúdo. São Paulo: Edições 70. 2011.

BRODERICK, G. A. Priapism and sickle-cell anemia: diagnosis and nonsurgical therapy. J Sex Med, v. 9, n. 1, p. 88-103, 2012.

CHROUSER, K. L., et al. Priapism in the United States: the changing role of sickle cell disease. American Journal of Surgery, v. 201, n. 4, p. 468-74, Abr. 2011.

CORDEIRO, R. C.; FERREIRA, S. L.; SANTOS, A. C. C. Experiências do adoecimento de pessoas com anemia falciforme e estratégias de autocuidado. Acta paul. Enferm, v. 27, n. 6, p. 499-504, Dez. 2014.

COUTINHO, M. P. L. Depressão infantil: uma abordagem psicossocial. João Pessoa: UFPB/Editora Universitária, 2001.

EKEKE, O. N. et al. Management of priapism in adult men. Int Surg. Vol. 100, n. 3, p. 552-557, mar. 2015.

MARTHA, D. et al. Revisão dos desenhos de pesquisa relevantes para enfermagem: Parte 2: desenhos de pesquisa qualitativa. Rev. Latino-Am. Enfermagem. Ribeirão Preto, v. 15, n. 4, Jul-Ago, 2007.

ROGHMANN, F. et al. Incidence of priapism in emergency departments in the United States. J Urol, v. 190, n. 4, p. 1275-1280, out. 2013.

VICARI, P.; FIGUEIREDO, M. S. Priapismo na doença falciforme. Rev. Bras. Hematol. Hemoter., São José do Rio Preto , v. 29, n. 3, p. 275-278, Sept. 2007

XAVIER, E. C. L. et al. Câncer de pênis: sob a ótica da representação social de pacientes submetidos à amputação de pênis e suas implicações para o cuidado de si. Interfaces Científicas - Saúde e Ambiente. Vol. 3, n.1, p. 39-46, out. 2014. 